Instructions for authors, subscriptions and further details:

Family Practices in the Construction of Creative Professionals. A Biographical Perspective

David Pac-Salas ${ }^{1}$

Cecilia Serrano-Martínez ${ }^{2}$

1) Universidad de Zaragoza, Spain

2) Universidad de La Rioja, Spain

Date of publication: October $25^{\text {th }}, 2018$

Edition period: October 2018-February 2019

To cite this article: Pac-Salas, D., Serrano-Martínez, C. (2018). Family Practices in the Construction of Creative Professionals. A Biographical Perspective, International Journal of Sociology of Education, 7(3), 256-277. doi: $10.17583 /$ rise.2018.3631

To link this article: $\mathrm{http}: / / d x . d o i . o r g / 10.17583 /$ rise.2018.3631

PLEASE SCROLL DOWN FOR ARTICLE

The terms and conditions of use are related to the Open Journal System and to Creative Commons Attribution License (CC-BY) 


\section{Family Practices in the Construction of Creative Professionals. A Biographical Perspective}

David Pac-Salas

University of Zaragoza
Cecilia Serrano-Martínez

University of La Rioja

(Received: 16 July 2018; Accepted: 21 September 2018; Published: 25 October 2018)

\section{Abstract}

The aim of this paper is to analyse the relationships between family configurations and creative occupations. For this purpose, a biographical perspective was taken through the reconstruction of the life histories of sixteen creative professionals in Spain. We have followed two lines of approach, namely Florida's classification of occupations (2002), which distinguishes between a creative class and a supercreative core, and Lahire's conception of family configuration (1995). The main results reveal the importance of practices that are carried out on a daily basis by the family network (both internally and externally): reading and writing, cultural consumption (theatre, music, exhibitions, etc.), types of leisure (travelling) and forms of authority that lead the way to self-control and domestic family order. We have shown with this study the importance of the transmission of family culture in the construction of people who have creative occupations and the relationship that exists between the family educational capital and the educational level attained by the offspring.

Keywords: creativity, creative professionals, family configurations, reading and writing culture, authority. 


\section{Prácticas Familiares en la Construcción de Profesionales Creativos. Una Perspectiva Biográfica}

David Pac-Salas

University of Zaragoza
Cecilia Serrano-Martínez

University of La Rioja

(Recibido: 16 Julio 2018; Aceptado: 21 Septiembre 2018; Publicado: 25 Octubre 2018)

\section{Resumen}

El objetivo de este artículo es analizar las relaciones entre configuraciones familiares y ocupaciones creativas. Para llevar a cabo esta propuesta utilizamos una perspectiva biográfica para la reconstrucción de las historias de vida de dieciséis profesionales creativos en España. Hemos seguido dos líneas de aproximación, la clasificación de las ocupaciones de Florida (2002) con la distinción entre clase creativa y núcleo supercreativo, la configuración familiar de Lahire (1995). Los principales resultados muestran la importancia de las prácticas educativas básicas en la red familiar (tanto interna como externa): lectura y escritura, consumo cultural (teatro, música, exposiciones, etc.), tipos de ocio (viajes) y formas de autoridad, el autocontrol y el orden familiar doméstico. Mostramos la importancia de la transmisión de la cultura familiar en la construcción de las personas que tienen ocupaciones creativas y la relación que existe entre el capital educativo familiar y el nivel conseguido por los descendientes.

Palabras clave: creatividad, profesionales creativos, configuración familiar, cultura lectora y escritora, autoridad.

2018 Hipatia Press

ISSN: 2014-3575

DOI: $10.17583 /$ rise.2018.3631
Hipatia Press www.hipatiapress.com

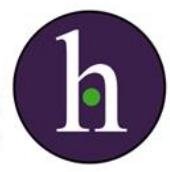


$\mathrm{T}$

he constant changes that take place and the high degree of uncertainty that exists in advanced capitalist societies are examples of forces that lead to the generation of problems and challenges which need to be resolved and faced through creativity (Alonso \& Fernández, 2013). Today, the discourse on creativity is acquiring ever greater relevance. Over the last few decades creativity-related matters have risen in prominence and importance in academic and political spheres, as well as in the media. For example, for Florida (2011, p. 279) "the fundamental right to fully develop and make use of one's creative talent" should form an integral part of the new social contract.

What is creativity? We take as our starting point the assumption, which while not adventurous does have important implications, that creativity has to do with the appearance of something new and therefore unplanned, instigated by the activity of some class of individual or collective agent, a definition which distinguishes it clearly from innovation, which is always planned and has specific predetermined goals.

In specific terms, the aim of this paper is to analyse the relationships between family configurations and creative occupations. We will answer the following question: what influences does a particular family configuration have on the educational path followed by those subjects who have creative occupations? According to our hypothesis, it should be possible to recognise some of the aspects connected with the characteristics of creative jobs in the biographies of creative professionals. In other words, we are dealing with people who throughout their lives have valued concepts such as autonomy, freedom, imagination, innovation, etc. Likewise, we would expect to find in their biographies an exploration of subjects in which artistic creativity finds its maximum expression: music, drawing, the plastic arts, etc.

The paper is structured in the following manner. An initial section analyses the research background with special emphasis on two principal aspects: firstly Florida's theory (2010) concerning the creative classes and its limitations and criticisms, and secondly the importance of the concept of family configuration (Lahire, 1995). The methodology used in the preparation of the paper is then described. In brief, the life histories of creative professionals were built up from a qualitative perspective. The third section describes the main results of the research undertaken. After reconstruction of the life histories of all the subjects had been concluded 
these were then compared and contrasted. The analysis undertaken in this study considers the life histories of the study participants through theoretical reflection and from a dialectic perspective, both theoretical and empirical. Finally, we present the conclusions of the study and comment in particular on its strengths and limitations.

\section{Background}

In recent years the concept of creativity has been examined from a number of perspectives. Depending on the discipline in question, several discourses can be found related to the understanding of what is meant by creativity. Various authors have considered the notion of creativity from the social science point of view. This is the case of Sawyer (2011) who differentiates between individual and sociocultural creativity, of Joas (2005) who supports a model of creative action, and of Csikszentmihály (1990) who attempts to define and measure creativity. However, the question of creativity has been a subject of interest for a number of years with contributions from numerous authors including Milgram (1990), Runco (1990), Rickards (1988), Arieti (1976) and Koestler (1989). One author who placed special emphasis on the study of creativity and education was Amabile (1983).

As for the question of creative occupations, Florida (2010) does not speak of a creative class as an economic class in terms of possessions, capital or means of production. For Florida, the creative class neither possesses nor controls ownership of means of production in the physical sense. As Florida argues (2010, p. 116), the possessions of the creative class come from its creative capacity and are intangible because they are, quite literally, in their heads. The process of identification of the creative class is an ongoing one and is given by the type of work the members of that class carry out. Tasks are undertaken in such works which consist of the creation of new and significant forms. According to Florida's definition, the creative class comprises two components: a) a super-creative core: scientists and engineers, university professors, poets and writers, entertainers, actors, designers and architects, and leading thinkers in modern society; and b) creative professionals; hi-tech sectors, financial services, legal and health professions, and company management. So, in Florida's approach the social classes are explained as principally occupational groupings. 


\section{Pac-Salas \& Serrano-Martínez-Creative Professionals}

With respect to creativity studies in Spain, the first work on the creative classes from an economic perspective was undertaken in the doctoral thesis of Casares (2010). Meanwhile, one of the first studies made from a sociological point of view was that of Navarro and Mateos (2010), who based their attempts to describe location patterns of the creative class in Spanish municipalities on fundamentally the occupation variable. Finally, there has been a spate of publications in recent years on the creative economy from a local standpoint and from a general geographical perspective. These include, amongst others, Boix et al. (2012), Sánchez Moral and Arellano (2012) and Méndez et al. (2012).

In our particular case, we have been working on the subject of creativity for a number of years. Inspired by the works of Florida (2002), we constructed creativity indices for Spain's autonomous communities and provinces. This was done by combining the indices of technology, talent and tolerance, which were in turn composed of another three subindices. Technology included R\&D, innovation and hi-tech, while the components of talent included the volume of the creative classes and the number of graduates and researchers. Finally, tolerance was measured, as in the United States (Florida, 2002), according to the amount of foreigners, bohemians and homosexuals. In this respect, we did not follow the methods of analysis used in Europe (Florida and Tinagli, 2004) which included attitudes towards minorities, self-expression and the index of values. According to the data we have obtained in our research into creativity (Báez et al., 2014 and Bergua et al., 2016), 20.23\% of occupations in Spain in 2001 could be described as creative. In other words, the use of creativity is required in the performance of tasks in one out of every five occupations. Among the main creative occupations we determined two types of activity: tasks pertaining to the running and management of companies and activities related to professions associated with university qualifications. The first group, activities involving company management, accounts for almost 4 of every 10 creative jobs in Spain, and the second group more than $55 \%$ of occupations. For occupations with university qualifications, teaching-related work accounts for 2 out of every 10 jobs, while professions in the scientific-technological field are responsible for 1 in every 10. The other most relevant occupations are found with professionals connected to the natural sciences and health, corresponding to $11.6 \%$ of creative professions. Writers and artists entail 
$3.3 \%$ of these occupations. If we consider the so-called super-creative occupations, top place in the ranking goes to secondary school and university teachers who account for almost half of these super-creative occupations $(21.9 \%)$.

In this study, we analyse the role of the family in the biographies of individuals who have creative occupations. Though different research studies have been undertaken on the importance of family models in education (Carbonero, 1997; Navarro Ardoy, 2006), more useful in our particular case is the concept of family configuration as proposed by Lahire (1995). This concept, central to Lahire's theoretical approach, entails conceiving family structures or dynamics not as the result of a family model or idea which the actors set in motion, but rather as the product of the interaction of the actions of the family members. Wall and Gouveia (2014) use the concept of family configuration to analyze changes in the Portuguese context (noting the need to incorporate the bonds of friendship in order to understand the familiar approach, transcending of the relatives).

From our perspective, the means by which family culture is transmitted is a highly relevant aspect in the construction of people with creative occupations. It has been shown that, in advanced societies, family education strategies have an ever-growing importance in the biographies of individuals. To analyse this we have introduced Bourdieu's concept of capital (2000, p. 131), namely that "capital is accumulated labour (in its materialised form or in its 'incorporated' embodied form)". And for this, capital is not reduced to its economic form but can appear in its different forms: economic, cultural, social and symbolic. In short, family configurations are not treated as a family model in which the young are entered but rather they are "the product of the interaction of the actions of all its members". The reconstruction of the life history of each of our study participants should not be limited to the family members but should include the external agents of socialisation who have been shown to be fundamental in the production of the practices of the creative subjects analysed. This entails, as described by Martín Criado (2000), "moving on from the language of variables, typical in statistical descriptions, to the study of the specific interweaving of relationships and interdependencies" or, as he also described it, "a set of relationships between some and other elements".

However, cultural transmission is not an automatic process (Lahire, 
1995). To be precise, what we have worked on, from a contextual perspective, is the transition from an abstract modelling of family factors (parental education level, socio-professional category, number of children, etc.) to the study of family configurations, taking into account all the different interdependencies. So, family factors do not impact mechanically on behaviour, but rather family configurations "are the result of the interdependency of a series of processes" (Martín Criado, 2000, p. 75). For Lahire (1995, p. 18-27), there are five factors in family configurations that affect relationships between family and school. Firstly, the family approach to reading and writing. Familiarity with reading and writing practices has an effect on scholarly success as well as influencing other aptitudes (control of time, attention to order, the ability to deliberate using oral language). Secondly, there is a need for particular economic conditions to be in place (with a certain degree of stability) for the fostering of a family culture of reading and writing and the morals of perseverance. In addition, domestic social order is required. In other words, good behaviour is encouraged as well as respect for authority, rules and order. The fourth factor highlighted by Lahire (1995) concerns the forms of authority. In this aspect, the similarity between school authority (based on obedience to disciplinary regulations) and family authority is essential. Finally, we have educational intervention models (family educational investment - in time and effort must be accompanied by affective involvement of the children in the culture). Nonetheless, this set of relationships and existing interdependencies should be taken as a whole.

A further clarification needs to be made. None of the different members of the family configuration occupies an identical position to any other. However, following Lahire (1995) and Martín Criado (2000), we must highlight the following aspects: a) conditions of availability of parental time, resources, etc., for the task of socialisation, b) the extent to which the influences that are received are concordant or divergent; and c) the economics of affective relationships within families. 


\section{Methods}

\section{Instruments}

We noted a few problems in the quantitative approach that we employed in other studies (Baez et al., 2014; Bergua et al., 2016). One of these was to the difficulty in answering questions concerning the emergence of creativity. Another concerned the excessive value given to numbers as opposed to the potentiality of a qualitative approach which was not reflected in these previous analyses. However, the quantitative perspective did allow us an etic viewpoint with which we were able to construct a map of creativity in Spain according to the previously described indices of Florida (2002); it is true that this approach did not fully answer questions related to the actual construction of a creative professional. So, instead of questioning the notion of creativity we resolved to make use of a qualitative approach to recover it. The reason for choosing this technique was because we consider it to be the most accurate means of knowing the different profiles and biographies of creative professionals. The aim was to find out how the creative professional is constructed. We understand that such a construction is carried out by combining different influences (family, social, cultural, etc.) that are embodied in a particular lifestyle and that generate the possibility of activating creativity. However, we also assume that the different types of capital as a whole and each on their own generate a certain diversity and heterogeneity which make a fertile soil for the emergence of creativity ${ }^{1}$. In our opinion, it seems that Florida wanted to make reference to this heterogeneity when he used the toleration index. As he was not successful in his attempt to use tolerance as a measure of creativity, we propose another way of analysing creativity using other methodologies.

It was our opinion that the best way of obtaining information about tolerance, understood as the merger of the different types of capital that generate the diversity and heterogeneity which gives rise to greater creativity, was through personal in-depth interviews which concentrated on the biography of the creative professionals. For the selection of profiles, we followed the classification of creative professions used by Florida (2002), which distinguished between a super-creative core (architecture and engineering, social, physical and life sciences, education, teaching and 


\section{Pac-Salas \& Serrano-Martínez-Creative Professionals}

lecturing, and art, design, entertainment, sports and mass media) and a creative group (positions of top management in companies and financial institutions, the legal sector, health and other specialist professions, top-level sales and sales management). We therefore developed a qualitative focus following a contextual perspective in order to establish a contextual framework of discovery.

\section{Participants}

The qualitative technique that we employed involved in-depth interviews to construct biographical accounts of the paths taken by creative professionals as life histories. The field work was carried out between March and June of 2012. A total of 16 life histories were elaborated of creative professionals from different autonomous communities in Spain (9 from Aragon, 2 from Galicia, 2 from the Basque country, 2 from Madrid and 1 from Catalonia) following a series of 48 interviews ( 3 per subject). The profiles of the 16 interviewees were as follows:

- Profile 1: Medium and large-sized company management and organisation. Male, over 40 years of age (bachelor and no children) (salaried employee, senior position).

- Profile 2: Professional in publicity or marketing. Female, below 40 years of age (married with 1 small child in nursery school) (selfemployed).

- Profile 3: Professor and researcher in the 'hard sciences' and in the public sphere (University, Research Institutions, Spanish National Research Council, etc.). Male, over 40 years of age (married with two daughters) (government employee).

- Profile 4: Artist (writer). Female, below 40 years of age (living with partner, no children) (salaried employee).

- Profile 5: Writers and artists (designer). Male, over 40 years of age (54) (married with two children) (self-employed).

- Profile 6: Doctors and veterinary surgeons. Female, below 40 years of age (married, no children) (resident physician, salaried employee).

- Profile 7: Law (lawyer, judge, etc.). Male, over 40 years of age (bachelor, no children) (self-employed). 
- Profile 8: Engineer. Female, below 40 years of age (separated from partner and recently entered into new relationship in Mexico, no children) (salaried employee, senior position).

- Profile 9: Architect or town planner. Female, over 40 years of age (divorced 3 years previously, 2 boys aged 12 and 11 and one daughter aged 7) (salaried employee working for the council of a medium-sized city in Catalonia).

- Profile 10: Economists, sociologists, historians, philosophers, philologists, psychologists and similar. (Entrepreneur-Historian). Female, below 40 years of age (married, no children) (selfemployed).

- Profile 11: Technical architect, IT specialist, architectural engineer. Female, over 40 years of age (married, with children) (entrepreneur, partner in architect centre).

- Profile 12: Mathematician, physicist, chemist, Masters qualified engineer, Masters qualified architect, etc. (scientist, chemical engineer). Male, below 40 years of age (married with one daughter) (government employee).

- Profile 13: Doctor, veterinary surgeon, pharmacist (family doctor). Male, over 40 years of age (married with two children) (government employee).

- Profile 14: Secondary and university teachers (secondary school teacher). Female, below 40 years of age (married with one daughter) (government employee).

- Profile 15: Management of specialist areas and departments, etc. (company manager, biologist and salesperson.) Male, below 40 years of age (married with 2 children) (salaried entrepreneur).

- Profile 16: Lawyers, district attorneys, judges, magistrates (lawyer). Female, below 40 years of age (married with two children) (selfemployed).

Following is a summary of the information provided above. The subjects are comprised of 9 females and 7 males, of which 9 are younger than 40 and 7 older, 2 are single, 11 married, 1 living with their partner, 1 separated and 1 divorced, 9 have children and 7 do not. In terms of type of employment, 9 are salaried employees, 5 are self-employed and 2 are entrepreneurs. With these interviews we were able to satisfy the criterion of theoretical 
saturation. That is to say, our sampling was concluded when we had obtained a significant data density for each analysis category (Trinidad, et al, 2006).

It should nonetheless be noted that the study does have some limitations. Though we concluded an analysis of the specific practices as narrated in the different family configurations with the elements connected with creativity, we nevertheless need to address creativity beyond the narratives in order to focus on the "black box" of creativity. That is, an in vivo observation of family practices would enable us to better understand some of the contradictions that have appeared in the study. However, this study provides a new way to understand the field of family sociology. This topic "has the potential to expand to meet the realities of 21 st-century family experience" (Farrel, et, al. 2012, p.297)

\section{Analysis of the Research. Family Influences on the Education of the Study Participants}

This section will analyse the role that family influences have had on the education of the study participants, as well as those elements that are connected with the educational system and the creativity therein generated. 


\section{RISE - International Journal of Sociology of Education, 7(3) 265}

Table 1.

Family Education Capital of the study participants

\begin{tabular}{|c|c|c|c|}
\hline & $\begin{array}{c}\text { Male parent } \\
\text { education capital }\end{array}$ & $\begin{array}{c}\text { Female parent } \\
\text { education capital }\end{array}$ & $\begin{array}{c}\text { Family } \\
\text { education } \\
\text { capital }\end{array}$ \\
\hline $\begin{array}{l}\text { Executive } \\
\text { (m) }\end{array}$ & Industrial labourer & $\begin{array}{l}\text { Housewife } \\
\text { Black market } \\
\text { employment }\end{array}$ & Low \\
\hline Publicist (f) & Banker & Housewife & Medium \\
\hline Scientist (m) & Veterinary surgeon & Pharmacist & University level \\
\hline Writer (f) & Automobile company & $\begin{array}{l}\text { Government } \\
\text { employee }\end{array}$ & Medium \\
\hline Artist (m) & $\begin{array}{l}\text { Professional military } \\
\text { man }\end{array}$ & Housewife & Medium \\
\hline Doctor (f) & $\begin{array}{l}\text { Electrician } \\
\text { Airport management } \\
\text { (engineer) }\end{array}$ & Exact sciences teacher & University level \\
\hline Lawyer (m) & Certified accountant & $\begin{array}{l}\text { Primary school } \\
\text { teacher }\end{array}$ & University level \\
\hline Engineer (f) & $\begin{array}{l}\text { Masters qualified } \\
\text { engineer }\end{array}$ & Nurse & University level \\
\hline Architect (f) & $\begin{array}{l}\text { Secondary school } \\
\text { level education }\end{array}$ & $\begin{array}{l}\text { Minimum education } \\
\text { level }\end{array}$ & Low \\
\hline $\begin{array}{l}\text { Entrepreneur- } \\
\text { Historian (f) }\end{array}$ & Pharmacist & $\begin{array}{l}\text { Doctor (left the } \\
\text { profession when first } \\
\text { daughter was born) }\end{array}$ & University level \\
\hline Architect (f) & $\begin{array}{l}\text { Personnel manager in } \\
\text { food company }\end{array}$ & Housewife & Medium \\
\hline Scientist (m) & $\begin{array}{l}\text { Secondary school } \\
\text { teacher }\end{array}$ & Nursing assistant & University level \\
\hline Doctor (m) & Farmer & $\begin{array}{l}\text { Farmer and } \\
\text { Housewife }\end{array}$ & Low \\
\hline Teacher (f) & Automobile industry & Salesperson & Medium \\
\hline Manager (m) & Pastry chef & Teacher & University level \\
\hline Lawyer (f) & $\begin{array}{l}\text { Agricultural and cattle } \\
\text { farmer }\end{array}$ & Housewife & Low \\
\hline
\end{tabular}

Source: compiled by the authors 
We first analysed those creative subjects whose institutionalised family education capital can be described as being of university level (one or both parents with a university education). In this group we find the female engineer, male lawyer, male scientist, female doctor, female historian, male biochemist and male doctor. This question serves to confirm the relationship between family education capital and the educational level attained by the corresponding offspring and, as will be observed subsequently, the transfer from parent to child of the value of education and of meritocracy. The education of the parents is found, for the most part, in a context of Spanish Catholicism, a system characterised by a curriculum based on selective and elitist goals (García Gracia, 2003, p. 96).

Secondly, we analysed those creative subjects whose institutionalised family education capital could be described as being sub-university level (neither parent with a university education). In this group we find the architects, the male artist, the male publicist, the female writer, the executive director, the female lawyer, the male doctor and the female secondary school teacher. As we will see subsequently, the family cultural practices with respect to education are very revealing in these family configurations.

With respect to the education of the offspring we were able to distinguish three types of intergenerational strategy: reproduction, reconversion and upward mobility. The strategy depends on the aim. If the idea is to maintain the resources that the family has, this is called a reproduction strategy. When the desire is to change a particular resource for another of a different nature, then a reconversion strategy is followed. Finally, if new resources are acquired with the objective of achieving a higher social position, then an upward mobility strategy is undertaken. These ideal strategy types are combined in real life giving rise to mixed or diversified strategies (Echevarría, 2005).

We also considered it important to analyse the mechanisms of mobility which are used in the class, group, family or individual strategies for the transmission or improvement of position in the stratification system. Such mechanisms include inheritance, marriage, the educational institutions, the family education, the labour markets and social influences and networks. 
Table 2

Intergenerational educational strategies

\begin{tabular}{ll}
\hline & $\begin{array}{l}\text { Intergenerational educational } \\
\text { strategies }\end{array}$ \\
\hline Executive director (m) & Upward mobility \\
Publicist (f) & Upward mobility \\
Scientist (m) & Reproduction \\
Writer (f) & Reconversion \\
Artist (m) & Reconversion \\
Doctor (f) & Reproduction \\
Lawyer (m) & Reproduction \\
Engineer (f) & Reproduction \\
Architect (f) & Upward mobility \\
Entrepreneur-Historian (f) & Reproduction \\
Architect (f) & Upward mobility \\
Scientist (m) & Reproduction \\
Doctor (m) & Upward mobility \\
Teacher (f) & Reconversion \\
Manager (m) & Reproduction \\
Lawyer (f) & Upward mobility \\
\hline Source: compiled by the authors &
\end{tabular}

Source: compiled by the authors

With respect to the reproduction strategies (corresponding to the female engineer, male lawyer, male scientist, female doctor, female historian, male scientist and male biochemist), we can see how in families with high family education capital there is a reproduction of this capital. That is, there is a resulting reproduction of creative class (parents to offspring). We also find among our subjects capital reconversion strategies (corresponding to the female writer, female artist and the female teacher), which change a particular resource (internalised educational capital) for another of a different nature (institutionalised educational capital). Finally, we have the upward mobility strategies (corresponding to the two female architects, male executive director, male doctor, female publicist and female lawyer) where qualifications rise from simple school leaving certificates to university degrees. In order to explain the divergence of educational paths in families with low family educational capital, the effect of the family configuration 


\section{Pac-Salas \& Serrano-Martínez-Creative Professionals}

(Lahire, 2013; Martin Criado, 2000) allows us to tackle the complexity of this phenomenon.

Concerning the decision as to which courses/subjects are to be studied, this is taken by the parents during the first years of schooling as it is they who choose the school to enrol the child. This can have a decisive effect on how their children think, on their thought processes. Parental influence on the early stages of education is direct, though rather than an influence it may be better described as a decision taken from within the family which is related to the values that the parents want their children to attain in the education system. As far as the role that parents have in the educational achievements of their children is concerned, Feinstein et al. (2008, p. 24) state that there exists an intergenerational transmission that is centred on educational success. In the same way, they explain, through their ecological model, that the key factors in infancy include the family, the pre-school environment, neighbours and peer groups. They include a conceptual model which shows the effects of the education that the parents exert on their children in terms of their academic performance. So, the influence of the parents is not only related to the choice of school. It is also important to evaluate the educational role that the parents played during their children's early years.

No. Really, the answer is no. Or rather, it was more than that I think; what they said to you was a sort of psychological punishment. I mean, they would say "the fact is you've disappointed me". And for your dad to tell you that you've let him down is like "Oh my God, where have I failed him?" So, it wasn't the sort of "you're grounded" punishment (female engineer).

Once adolescence is underway, the influence of a close-at-hand family environment becomes less intense. During this vital period, the influence of the individual's group of friends or classmates, or in other words the peer group influence, begins to gain in importance. One example of this disengagement from the family core is that adolescence is the time when the child's own opinion about the choice of school itinerary begins to have more weight. As for higher education, whether this is in vocational training or is university-based, there is no common pattern as to the possible influences of the parents on the choice made. Some of the participants in the study felt 
themselves attracted to a particular type of university degree from an early age, as was the case of the female architect. According to Winnicott (1971, p. 150), adolescents "must make a jump to a false maturity". Winnicott adds that in cases when parental figures abdicate their responsibilities in the upbringing of their offspring at adolescence the children would be losing their most important asset, namely the "freedom to have ideas and to act on impulse". However, some narratives of the study participants indicate that the interest in a particular academic area grew as a result of the influence of a teacher who gave classes in that subject, or because they found the content relatively easy or as a consequence of some specific guidance or advice.

I had a teacher in Spanish Language and Literature in my final year who was also my class tutor. I used to say to myself "I want to be like him. I like the way he acts and everything" (secondary school teacher).

I'll never forget a woman teacher we had for the final year of biology who then left the school. She gave us really good guidance in our studies, I mean in terms of advising us about how to prepare for university" (male doctor).

The hobbies that they had in the family home from an early age, such as reading and art, were determining factors in the subject choices made by the female historian and the female philologist. Allowing himself to be led by instinct or what could almost be described as fate was what most influenced the chemist. As we can see, the choice of studies is fundamentally underscored by intrinsic (personal motivation, sensations) and extrinsic (hobbies learnt, teacher admiration) criteria.

As for the contextual aspects that are reflected in the life histories of our participants, specifically in those experienced in the primary and secondary socialisation processes, one of the first aspects is the existence of books in the family home. There is considerable empirical evidence about the relationship between the presence of books in the family and the educational achievements of the children in that family. The fact that a household contains books however does not necessarily mean that they are read, and it is the role of the parents that is vital as far as family reading habits are concerned. 


\section{Pac-Salas \& Serrano-Martínez-Creative Professionals}

Of the activities that the participants engage in in their free time, the one that most stands out is reading. This is an activity that for them has become a habit acquired when they were little and which continues to thrive. One of the incentives that helped inculcate this habit was the presence of books in the family home. At school too there were activities allotted exclusively to the practice of reading. Such is the value that they attach to this activity that, to a greater or lesser extent, they try to read every day or, at the very least, on a weekly basis. When the reading is not directly work related, they try to find more relaxed times of the day like before going to bed.

There have always been lots of books in my house. I always remember from when I was a little girl seeing the room that my father used as a study full of books (female lawyer).

In many cases expressions were used by the study participants referring to the fact that they had "many books" or that "there are more books than anything else". As also noted by Lahire (2005), another fundamental aspect in this influence is that of observation in a family context; the fact that they could continually see their parents, siblings, etc., reading. In the case of the female doctor, not only were both parents avid readers but also her godparents. The parents also enjoyed another hobby that is very interesting in terms of the construction of a creative spirit: travelling. For her part, the female writer highlighted the presence of books, attending cultural events, light opera, theatre, cinema, etc., in her biography and in that of other members of her family, in particular her brother.

In my family, in general, everybody reads quite a lot. Then, I have a special relationship with my godparents who've been like second parents to me, (...) they're people who read an awful lot ... she studied Hispanic language and Culture and is a Spanish Language and Literature teacher in the same college as my mother and he's an engineer and for many years was a company manager ... They're people, you know, who have always instilled that sort of thing in us. Travelling is also very important in my family (female doctor).

What they always used to do was to take us out a lot, and to places a bit unusual for children. They would take us to see light opera, to the theatre, we went to the cinema a lot, to eat out (...) My brother is an 
actor in the theatre. And, I reckon, some of that love of art and of culture and books and so on, has come from our parents, from both mum and dad ... they've always tried to instil in us a love for reading and for being, how can I explain it, connected with life, if you know what I mean (female writer).

In her narration, the female architect reported there were few books in the family home. In her biography it is rather glimpses of the importance of magazines that we find. In this case, the magazines (home decor, space design, etc.) are strongly related to her current profession. Also of great influence were the games she used to play as a child with her friends (particularly games involving spatial organisation, etc.). Also important was the figure of her grandfather in relation to spatial reorganisation in the construction of the family restaurant.

Well, this, yes... I remember that from when I was just a little girl... You know, magazines and books about spaces and that, I used to like a lot (...) I would spend the whole weekend doing charcoal drawings. I wanted tempera paint, tempera that was it... I suppose it was a bit of wanting to experiment and try out new things (female architect).

The biography of the female publicist is a clear example of the importance of the extensive social network of the family. As opposed to the order that she found in her home, she would find things were less tidy and somewhat more chaotic in the house of her parents' friends. The customs of different people, their arrangement of spaces, their choice of presence of books, music, etc., help us to understand the diversity of ways of life.

Birthday parties were normally held, well, at home, Schoolmates would then come to your house or we would go to theirs. Then, my parents used to have a lot of friends and I remember that we went out a lot to the houses of German friends of my parents who used to do barbecues (...) I was struck by some of their customs... For example, listening to classical music, because in my house we played flamenco, Spanish music, but I hadn't listened, like that, to classical music in a more, I'm not sure how to describe it, scholarly way perhaps. And there were other types of music that we would listen to there as well (female publicist). 


\section{Pac-Salas \& Serrano-Martínez-Creative Professionals}

In his narrative, the scientist places particular emphasis on a writing ritual. He was at a boarding school and every weekend the pupils used to have to write a letter to their parents. In other studies (Lahire, 1995; Martín Criado, 2000), these writing practices have been shown to have a positive influence on a student's academic results.

We boarders would write the letter... we would be obliged to write the letter to our parents each weekend and they would come to see us on the occasional Saturday afternoon and we'd go home in the school holidays (male scientist).

To conclude this section, we focussed on two aspects that are related and are extremely relevant in terms of the relationship between the family and the school world: the form of family authority and domestic moral order. The question of authority is of great important in our opinion. A lot of importance is also given in families to the domestic moral order, that is whether our child behaves properly and respects the teacher's authority (Lahire, 1995, p. 23). Cases were told to us of strict teachers, and of others who were more approachable and who inspired greater trust. The recollections of teachers that have stayed in the mind of our study participants are related to the learning abilities that they acquired from them, regardless of their emotional intensity.

He was a guy with extreme right-wing ideas, but he loved biology and transmitted that love to us. He may well have been the strictest teacher I've ever had in my life and he's the only one whose face and name I can remember. He was strict but fair and it was very clear how much he adored biology. You could say it was his fault, or thanks to him, that I ended up studying biology (manager, biologist).

As far as strategies to ensure the maintenance of authority is concerned, in some cases, as with the female doctor, rather than speaking about punishments there is more talk of restrictions and obeying established rules. In some cases, responsibility in family educational practices was passed on to the children themselves in the educational sphere. The children were thus left to their own ends. The interviews reveal that on occasions an excess of freedom and a lack of control on the part of the parents can, as also 
suggested by Lahire (1995), lead to the responsibility for studying and advancement in their school activities being left to the children.

I don't know if I would call it punishment. My parents weren't into punishing as such. I think they were more restrictive than punishers (...) Then, if I wanted to do something and wanted to go out with my friends somewhere and they wouldn't let me, I'd argue and quarrel and fall out with them. But as for actually punishing me, I wouldn't call it that (female doctor).

I was the youngest and they didn't give a damn about me. It was unbelievable, you know, and I remember at a school celebration we had when I was around 16 and we had to perform a dance and I was the only one (...), they just didn't care in the slightest about me and they didn't come (entrepreneur, historian).

With respect to the interest that parents have in the upbringing and education of their children, Coleman (2011, p. 739) suggests that there are three dimensions in which it is possible to observe the potential conflicts that are generated between society and family. The first of these is the confrontation that exists between the family's "values, orientations, customs, language, rules and culture" and the social order, making this a cultural conflict. Secondly, we have an educational conflict, in that on the one hand the family is interested in using its own resources to educate their children, while on the other society seeks to avail itself of the resources of the family. Thirdly, there is a generational conflict, as parents are interested in investing their resources in themselves, whereas the social order attempts to use up the parents' resources for the next generation.

\section{Conclusions}

An analysis has been undertaken in this paper of the influence of different family configurations in the social construction of professionals who use creativity in their fields of work. A biographical approach was used for this purpose through 16 life histories of creative Spanish professionals, following the methods of Florida (2002) and Lahire (1995). The main conclusions are concerned with the extent that family influences affect the selection of 


\section{Pac-Salas \& Serrano-Martínez-Creative Professionals}

course studies as well as the effect that the transmission of family culture itself has on the choices made with respect to a particular professional profile. We have therefore answered the question as to whether there exists some type of relationship between family educational capital and the educational level attained by the offspring or, in this particular study, by these creative professionals. We have also seen the influence that a specific family configuration has on the educational pathway followed by our subjects with creative occupations.

With respect to the question of family influences on education, it should be noted that parental values are important to the extent that it is the parents who choose the school itinerary in the early years of education. So, primary socialisation is of fundamental importance in the construction of educational patterns and models. In the same way, the choices made by the study participants about the courses they would take were influenced in many cases by the hobbies and pastimes of their parents. The importance was also observed of the educational institutions and the family education in intergenerational strategies.

Different family cultural capitals are transmitted from different practices. On the one hand, a key aspect is the practice of reading, both in the family and at school. Existing books and daily reading practices at home, as well as activities related to reading at school, together with space layout, the presence of books, etc. On the other hand, the enjoyment and pleasure for activities related to art (attending exhibitions), music (concerts, playing instruments, etc.), cultural activities (cinema, theatre, etc.), as well as pleasure for travel helps to create an ecosystem where diversity and heterogeneity is part of the lives of future creative professionals.

We have shown with this study the importance of the transmission of family culture in the construction of people who have creative occupations. The cases that have been analysed reveal diverse family educational strategies which have a significant impact on the life histories of the study participants. Another key point of this study is the confirmation of the relationship that exists between the family educational capital and the educational level attained by the offspring. Paternal authority has a fundamental effect on the relationship between parents and offspring, as does the value that the parents attach to meritocracy and the extent to which they transfer this value to the education of their children. In most cases, at 
least one of the parents in our study held a university degree. This aspect has influenced the educational dynamics that have subsequently guided these creative professionals in that, in an analysis of intergenerational educational strategies, it was found that most of them have followed a strategy of reproduction (seven cases) or upward mobility (six cases).

\section{Acknowledgements}

This article is a result of the research "Creative classes in Spain: Composition, development and creativity" financed by the Ministry of Economy and Science (ref. CSO2010-17139). Also, authors appreciate the funding received from the Risk Society Studies Group through the Diputación General de Aragón.

\section{Notes}

1 Freud goes further (Arieti, 1976: 22-26) when suggesting that creativity, like neurosis, arises from conflicts. In his opinion, the creative person is a sexually frustrated type who sublimates the conflict. There is nothing in the lives of our subjects which could lead us to think of the construction of the creative professional in these terms.

\section{References}

Alonso, L.E. \& Fernández, C. J. (2013). Los discursos del presente. Madrid: Siglo XXI.

Amabile, T. M., (1983). The social psychology of creativity. New York: Springer-Verlag.

Arieti, S., (1976). Creativity. The magic synthesis. New York: Basic Books Baez, J.M., Bergua, J.A., \& Pac, D. (2014). The Creative Class and the Creative economy in Spain, Creativity Research Journal, 26(4), 418426. doi: 10.1080/10400419.2014.961769

Bergua, J. A., Pac, D., Báez, J.M., \& Serrano, C. (2016). La clase creativa. Una aproximación a la realidad española, Revista Internacional de Sociología, 74 (2). e032. doi: 10.3989/ris.2016.74.2.032

Boix, R., Lazzeretti, L., Capone, F., de Propris. L., \& Sánchez, D. (2012).

The geography of creative industries in Europe: A comparison analysis in Italy, France, the United Kingdom and Spain in Lazzeretti, L. (ed.). Creative industries and innovation in Europe: Concepts, Measures and Comparative Case Studies, Routledge 
Bourdieu, P. (2000). Poder, derecho y clases sociales. Bilbao: Desclée de Brouwer.

Carbonero, M. A. (1997). Las estrategias laborales de las familias en España. Madrid: CES.

Coleman, J. S. (2011). Fundamentos de teoría social. Madrid: CIS Csikszentmihály, M. (1990). The Domanin of Creativity, in Runco, A., \& Albert, R. S. (1990). Theories of creativity. California: Sage Publications

Echevarría, J. (2005). La movilidad social: teorías, conceptos y aspectos metodológicos. In J.J González y M. Requena (ed.) Tres décadas de cambio social en España. Madrid: Alianza.

Farrel, B., VandeVusse, A. \& Ocobock, A. (2012). Family change and the state of family sociology. Current Sociology, 60(3), 283-301. doi:

$10.1177 \% 2 F 0011392111425599$

Feinstein, L., Duckworth, K., \& Sabates, R. (2008). Education and the Family. Passing success across the generations. Abingdon: Routledge Florida, R. (2002). The rise of the creative class. New York: Basic Books Florida, R., \& Tinagli, I. (2004). Europe in the Creative Age, Carnegie Mellon Software Industry Center, Alfred P. Sloan Foundation and Demos.

Florida, R. (2010): La clase creativa. La transformación de la cultura del trabajo y del ocio en el siglo XXI. Barcelona: Paidós.

Florida, R. (2011). El gran reset. Barcelona: Paidós.

García Gracia, E. (2003). El sistema de enseñanza como construcción histórica y social. In F. F. Palomares (ed.). Sociología de la educación (87-116). Madrid: Pearson Prentice Hall.

Goleman, D., Kaufman, P., \& Ray, M. (2009). El espíritu creativo.

Barcelona: ZETA

Joas, H. (2005). The creativity of action. Cambridge: Polity Press.

Koestler, A. (1989). The act of creation. England: Arkana.

Lahire, B. (1995). Tableaux des families. Heurs et malheurs scolaires en milieu populaires. Paris: Gallimard.

Lahire, B. (2013). Dans les plis singuliers du social. Individus, institutions, sociolisations. Paris: La Décourverte

Martín Criado, E. (2000). Familia de clase obrera y escuela. Donostia, Iralka. 
Mendez, R., Michelini, J. J., Prada, J. \& Tebar, J. (2012). Economía creativa y desarrollo urbano en España: una aproximación a sus lógicas espaciales. EURE, 38(113), 5-32.

Milgram, R. M. (1990). Creativity: An Idea Whose Time Has Come and Gone? in Runco, M. A., \& Albert, R. S. (ed.). Theories of creativity. California: Sage Publications

Navarro, C.J. \& Mateos, C. (2010). La clase creativa en los municipios españoles. Propuesta de medición y análisis descriptivo. DT 04/10. Sevilla, Centro de Sociología y Políticas Locales, Universidad Pablo de Olavide.

Navarro Ardoy, L. (2006). Modelos ideales de familia en la sociedad española, Revista Internacional de Sociología, 43, 119-138. doi:10.3989/ris.2006.i43.43

Rickards, T. (1988). Creativity at work. Aldershot: Gower publishing company

Runco, M. A., \& Albert, R. S. (1990). Theories of creativity. California: Sage Publications

Sánchez Moral, S. \& Arellano, A. (2012). El empleo en la economía del conocimiento en España: características socio-profesionales y patrones de distribución territorial. Scripta. Nova Revista Electrónica de Geografía y Ciencias Sociales, XVI, 399.

Sawyer, R. K. (2011). Explaining Creativity: The Science of Human Innovation. New York: Oxford University Press.

Trinidad, A., Carrero, V. \& Soriano, R.M. (2006). Teoría fundamentada $<$ Grounded Theory> La construcción de la teoría a través del análisis interpretacional. Madrid: Centro de Investigaciones Sociológicas.

Wall, K. \& Gouveia, R. (2014). Changing meanings of family in personal relationships. Current Sociology, 62(3), 352-373. doi:

$10.1177 \% 2 F 0011392113518779$

Winnicott, D. W. (1971). Playing and reality. London: Tavistock Publications.

David Pac-Salas is Professor at University of Zaragoza, Spain Cecilia Serrano-Martínez is Professor at the University of La Rioja Contact Address: davidpac@unizar.es 